ISSN 2075-4698

www.mdpi.com/journal/societies

Article

\title{
Of Plants, and Other Secrets
}

\section{Michael Marder}

IKERBASQUE, Department of Philosophy, The University of the Basque Country, Vitoria-Gasteiz, 01006, Spain; E-Mail: michael.marder@gmail.com

Received: 1 December 2012; in revised form: 20 December 2012 / Accepted: 21 December 2012 / Published: 27 December 2012

\begin{abstract}
In this article, I inquire into the reasons for the all-too-frequent association of plants and secrets. Among various hypotheses explaining this connection from the standpoint of plant morphology and physiology, the one that stands out is the idea that plants are not only objects in the natural environment, but also subjects with a peculiar mode of accessing the world. The core of the "plant enigma" is, therefore, onto-phenomenological. Positively understood, the secret of their subjectivity leaves just enough space for the self-expression and the self-interpretation of vegetal life.
\end{abstract}

Keywords: plant ontology; subjectivity; enigma; fetishism; phenomenology

\section{The Secret of Vegetal Subjectivity}

With remarkable insistence, the word "secret" has insinuated itself into the titles of books, symposia, films and TV programs seeking to shake up the commonsensical understanding of plants. Arguably, the most cited example and the pioneer of this trend is Peter Tompkins and Christopher Bird's 1973 The Secret Life of Plants: a Fascinating Account of the Physical, Emotional, and Spiritual Relations Between Plants and Man [1], which has become something of a cult book and the basis for a homonymous 1979 documentary directed by Walton Green. Then, there is the more recent monograph by Florianne Koechlin, Pflanzenpalaver: Belauschte Geheimnisse der botanischen Welt [Plant-Chatter: Secrets Overheard from the Botanical World] [2], featuring interviews with organic farmers, philosophers, cell biologists, artists, and others_-all taking part in an attempt to dispel the prejudice that plants are nothing but simple biological machines. To the above, we might add Emily Goodman's book for children, Plant Secrets [3]; a Canadian TV special Smarty Plants: Uncovering the Secret World of Plant Behavior, aired in September 2012 on CBC’s “The Nature of Things” [4]; a conference 
organized in May 2013 by Princeton University’s Interdisciplinary Doctoral Program in the Humanities and titled, not surprisingly, The Secret Life of Plants... The list goes on.

Why this strange intimacy of plants and secrets in popular culture, as well as in the academic world? What sets plants apart from all other creatures, turning them so mysterious? Whence our growing fascination with these "growing beings"?

A somewhat sympathetic skeptic would retort that the discursive inflation of secrecy is the symptom of an overreaction to the millennia-old disregard and neglect of plants, invariably pre-conceived as something utterly obvious and, in the first instance, as nearly inanimate things. Those who clamor after plant secrets swing to the other extreme of fetishizing the creatures they are so enthralled with. To the disenchanted, modern, scientific construction of nature, they oppose an enigmatic remainder that has found refuge in the vegetal capacities still unknown to us. Even as they wage an uphill battle against the reductive and objectifying view of the botanical world, plant enthusiasts render the green subjects that beguile them quasi-sacred and, hence, deserving of veneration, which, at times, borders on religious worship. ${ }^{1}$ In so doing, they provide a supplement to the dominant paradigm, a soulful niche that, as Immanuel Kant would have it, makes life in a heartless world tolerable. Therefore, as the argument would go, the exception embodied in these enthusiasts proves the rule that those who suffer the greatest abuse are often submitted to the highest degree of fetishization. (Suffice it to think of the duplicitous "Madonna/whore" attitude toward women in patriarchal societies to realize how deification and violation can function as mutually reinforcing tendencies.)

There is more than one grain of truth in this assessment. But, that is not to say that it is either fair or exhaustive. Although plant fetishism is an ever-present prospect looming on our theoretical horizon, we should be alive to the fact that it is a byproduct of the newly discovered (or, perhaps, long forgotten and recently re-discovered) evidence for the existence of plant subjectivity. If one refers to the short list of titles I have compiled above, one will note that, without exception, they indicate that the plant is not only an inert what, but also a who: a party in "physical, emotional, and spiritual relations", a whisperer of its peculiar knowledge, a center of intelligence or an agent capable of behaving in one way or another. And this leads me to my first hypothesis, namely that there is an intrinsic bond between the plants' who-ness and their enigmatic status.

To resort to the Kantian philosophical jargon, secrets are the upshots of the transcendental illusion that faithfully shadows subjectivity — a necessary illusion, which makes us believe that, behind diverse actions and behaviors, there is a subject who is their origin and cause. Mutatis mutandis, behind plant behavior is vegetal subjectivity, which should not, however, be conflated with that of animals or humans. Given that they behave by changing their states, rather than by fleeing or approaching elements in their milieu, the modes of plant activity and passivity differ from those of non-sessile beings. Vegetal behavior, expressed in changes of state, is already an enigma. Add to this the Kantian transcendental illusion, and plant life will become ever more enigmatic! Just as a secret is both conceptually and etymologically separated, set apart, withdrawn or hidden (secretus = se, on one's own, without, apart + cernere, separate) from knowledge, if not from the knowable order as such, so

1 Elsewhere, I discuss the risks of such fetishization, while distinguishing between the religious and the ethical approaches to plants. See, for instance [5]. 
subjectivity is insulated from the tangible, empirical world. Do plant-subjects, too, obey the logic of this withdrawal?

At first blush, plant subjectivity is still more hidden than that of animals and humans. It is not for nothing that St. Thomas Aquinas, having failed to discover in vegetation the qualities of sentience and movement, made the pronouncement vita in plantis est occulta, "life in plants is hidden", in Summa Theologica ([6], Q.LXIX, A2). The Thomist plant is a crypt, a place where vitality is encrypted, or, as the preposition in testifies, a deep and inaccessible reserve of a barely recognizable life. It is this occult remainder that gives rises to fertility cults and totemism, as much as to culture and signification in general, as theorized by Emile Durkheim, Theodor Adorno and Max Horkheimer. So exacerbated, the enigma of subjectivity flips into its opposites: a thoroughgoing objectification of plants, their obviousness and inconspicuousness, not to mention their subsequent unbridled instrumentalization.

Following a fundamental law of metaphysics, the unapparent is the origin of appearances, a secret cause inexhaustible in its effects. Like St. Thomas, Dante, in his Divine Comedy, subjects plants to this law by isolating their life (now dubbed "substantial form”) from its observable signs. Substantial form “...is not perceived except when in operation, / And is never manifest except in its effects, / As the life of a plant is by its green leafs" ([7], "Purgatorio", Canto XVIII, ll.52-54). In the Northern Hemisphere's winter, approaching a tree that is not evergreen, you could easily mistake it for dead wood. Life may not be entirely absent, but its obstinate refusal to show itself, at least in its effects, transforms it into a metaphysical secret.

Today, the quest for the secret source of plant subjectivity - that is, for a unified origin of its complex behavior-has become the new philosopher's stone in certain corners of botany. Plants admittedly juggle many, oft-times conflicting, stimuli, such as light, heat, gravity, soil gradients, and so forth, that require a wide range of responses [8]. But, it is an unwarranted leap, beholden to the twin ideas of metaphysical causality and totality, to assume that the subjectivity that takes up these stimuli is a unified center of decision-making. "Signal integration", molding the plant into a living information-processing machine, is the scientific name for the Kantian transcendental illusion. Of course, instead of genuine secrets, scientists deal with what, like a flower still in a bud, is only provisionally unknown, with problems yet unsolved, for, sooner or later, a particular biological process—say, hormonal signal integration [9] — will fill in the gap in the order of knowledge. But, a more promising conclusion would be that plant subjectivity is a dispersed set of effects devoid of a cause, substantial form, integrated source, or depth... and so are we. Nietzsche, following the lead of Hume, famously pointed out that the human subject is an unavoidably belated fabrication, a doer's insertion post factum into the deed ([10], p. 25). The sole disadvantage of the Nietzschean critique is that it is impotent in the face of the transcendental illusion, which is necessary, precisely, as an illusion, for without it, we would not muster enough energy to go on living. Plants, on the other hand, do not require such self-deceptions to keep growing, since their meaning and sense lie elsewhere. The secret is that there is no secret.

\section{Face-to-Face with a Tree?}

Let us continue gyrating in the constellation of plants and secrets, as we try out a different orbital approach. Could it be that plant morphology holds the key to this relation? The root, after all, has 
always served as the perfect metaphor of the first principle, profound radicality and originality withdrawn from the world of the senses. A source of life buried in the darkness of the soil, it is the symbol of obscurity that makes what is visible possible. The root, in other words, is the preferred figure of metaphysics, one that philosophy, in all its radicality, strives to grasp, to unearth, to return to and to make its own. But, at this point, the analogy breaks down: to uproot a plant is tantamount to destroying it, unless we do so in order to transplant it into a different soil, or, say, into a larger pot. And philosophical grasp, unsettling common sense and provoking the uncanny feeling of wonder, is, at least metaphorically, an exercise in uprooting. Be this as it may, the act of uprooting has an air of obscenity about it, revealing what belongs far away from the realm of the visible and violating a secret. It could well be that the history of metaphysics, or, in other words, of Western philosophy as Heidegger understood it, is a history of the uprooting of Being, whereby it is named Idea, God, substance, subject or whatever else. As misnomers, these keywords of intellectual history flashed the root but for a moment, immediately burying it back in the ground of metaphysics, transplanting it from the soil of one master-signification to another. Heidegger, in turn, was the one who, in naming Being "Being", indulged in the ultimate obscenity, finally tore the philosophical root from its (invariably ideal) soil, and called this uprooting "the closure of metaphysics."

Abstract as it may sound, for Heidegger, the depletion of the ethereal metaphysical foundations for philosophizing makes it possible, for the first time in human history, to see the world for what it is, and not as an epiphenomenal manifestation of withdrawn causes and hidden meanings. Having eschewed the ideal ground of thinking, we can finally stand face-to-face with other beings, and, most tellingly, with a blossoming tree:

We stand outside of science. Instead we stand before a tree in bloom, for example—and the tree stands before us. The tree faces us. The tree and we meet one another... As we are in this relation of one to the other and before the other, the tree and we are. This face-to-face meeting is not, then, one of those 'ideas' buzzing about in our heads ([11], p. 41).

No secrets, no mysteries, no scientific puzzles_-just us and the tree, in a mundane encounter that had been hitherto unthinkable because of the biases, expectations and ideas we project and interject between ourselves and the surrounding world. Released to the realm of Being ("the tree and we are"), we can finally meet the plant without any undue interference, right on the ground wherein it is rooted. Except that the tree has no face and, therefore, cannot participate in a face-to-face encounter! To attribute a face to a tree is to project something extraneous onto it, succumbing to "one of those 'ideas' buzzing about in our heads.” It is to reintroduce a secret into the very process of demystification that struggles to do away with metaphysical obscurantism. The tree itself escapes and seals itself from our grasp as soon as we associate it with a face or a posture-in a word, with an anthropomorphic stance.

What Heidegger's infelicitous expression teaches us is that the secret of plants can be ontological, though not, at the same time, metaphysical. It is hardly sufficient to cast off a metaphysical frame of reference in order, immediately, to receive the world just as it is given to us, since large regions of it are decidedly not given, but are set apart and withdrawn. The plants' non-givenness has to do with the divergence of the time-scale of their lives from ours, not to mention the variance of their world and modes of accessing it from our own. While the originally vegetal time of growth, as well as of decay, belongs to our bodies and their organs, we are largely asynchronous with the plants. (Truth be told, a 
similar non-synchronicity affects our relation to ourselves, or at least to those aspects of our biological life that escape our conscious monitoring and control.) That is why a face-to-face relation to plants is a non-starter: just when we are convinced that we have finally met them, they are no longer (or not yet) there, since we have neither the patience nor the capacity to linger with them, to accompany their development and growth. Unless one is a farmer, Heidegger would rejoin in one of his nostalgically bucolic moods, for, the farmers' own temporality is dependent on the forbearing with which they expect the crops. But, then, a nagging question arises: In this lingering-with, what happens to "our ek-sistent essence,” which separates us from all other living beings “by an abyss”? ([12], p. 230).

\section{Plant Secrets, Human Secrets}

However suggestive, the subterranean position of the root does not explain the plant/secret nexus. Perhaps, rather than the root itself, it is the attachment of plants to the soil that makes all the difference: for mythic thinking, the seed's germination from the earth testified to the vitality of the latter, borrowed, as it were, vicariously by the growing plant. Such ancient animism resonates across the philosophical tradition, from St. Thomas's interpretation of Biblical Genesis to Hegel's Philosophy of Nature, where the plant negates, and, at the same time, elevates and preserves (in a word, sublates) the entire mineral realm that has preceded it. The secret is dialectically tied to the calculated displacement of the seed prior to its germination, its hiddenness in the earth that enables it to emerge to the light of day, symbolically encapsulating human Bildung, the progression from unconscious Spirit to Spirit fully conscious of itself. Secrecy and darkness are, on this view, the very embodiments of negativity and of resistance that are to be overcome, fueling the process of growth along the way. As in the case of scientific optimism, mystery construed in terms of relative negativity would be merely provisional, even if the continuation of growth were assured solely on the condition that the plant (and with it the whole of Spirit) remained rooted in the dimness of the soil that nourishes it.

The paradox of searching for secrets in plants attains its starkest form as soon as we relate the etymological sense of secrecy to the subjectivity of vegetal life. Granted: plants are not entirely passive creatures, but neither do they construct their subjectivity by separating from and opposing themselves to the rest of their milieu, in the manner of an animal or a human. Hegel, too, was well aware of this quality of vegetal subjects that operate by way of exposure (for instance, to solar radiation) instead of interiorization. A secret implies the latter process - therefore, the kind of segregation and detachment that is consonant with the animal and, even more so, with the human psychic realms. But, what is set apart and thus converted into a secret there where nothing is set apart from the physical environment? And, first of all, a secret for whom?

It is time to recall that the loci of secrecy are multiple and that they lie not only in the plants' hitherto unknown capacities (such as communication through sounds [13]) but also in our relation or, better, asynchronous non-relation to our green cousins. It would be fair to say, then, that to the creatures, such as ourselves, who tend to conflate the psyche with the invisibility of "inner life," existence without depth and a subjectivity open to the world appear strange and incomprehensible. From the standpoint of anthropos, a soul without the privacy of psychic space (that is to say, a plant-soul) can only present itself as an enigma. 
In the history of Western metaphysics, a well-defined teleological narrative has structured the emergence and demarcation of the private, inner, psychic space as the culmination of a long process of spiritualization, interiorization and cultivation of subjectivity. Essentially hidden from others, psychic interiority reveals itself the moment it is produced or invented in confessional discourse that schizophrenically cherishes and breaks the secret.

On this triumphant march of interiority, the vegetal heritage of animals is an obstacle, in that it shields their vital core from sight:

The real seat of the activities of organic life remains veiled from our vision; we see only the external outlines of the animal's shape, and this again is covered throughout by feathers, scales, hair, pelt, prickles, or shells. Such covering does belong to the animal kingdom, but in animals it has forms drawn from the kingdom of plants ([14], p. 145).

It is worth noting the complexity of this figure, where the empirical visibility of plant-like coverings occludes and mystifies the organic life of animals. Human beings, according to Hegel, are spared this fate:

The human body, on the contrary, stands in this respect at a higher stage, since in it there is everywhere and always represented the fact that man is an ensouled and feeling unit. The skin is not hidden by plant-like unliving coverings... ([14], p. 146).

The secret of human subjectivity can finally manifest itself in the exposedness of the always-already spiritualized body, no longer obstructed by vegetal coverings. An expression of psychic interiority and a reflection of extreme sentience, this body's nakedness has nothing to do with the absence or presence of its external clothing and everything to do with the fact that it has, by and large, shed the vegetal heritage of animal life. Assuming that the Fall of Adam and Eve was the fulcrum of their humanization, their realization that they were naked meant that they had definitively left not only their animal, but also their vegetal condition, symbolized by the "unliving coverings," behind. From now on, two distinct modes of exposure will compete for our attention: the one hiding the vitality of plants-along with everything plant-like growths cover-and the other imperfectly reflecting the "swelling of life" or "the pulsation of blood" that "shows itself over the entire surface" of the ensouled human body ([14], p. 146).

\section{4. "From the Broken Shoot, Both Words and Blood”: Toward Phytophenomenology}

If, today more than ever before, the meaning of plant life retains the allure of secrecy, this is not because we have not yet interpreted it well or thoroughly enough, but because it's a matter of the plants' self-interpretation and self-expression. Let me be perfectly clear: I am not claiming that plants have selves that are exactly like those of humans, nor am I imputing to them the capacity for a symbolic or representational interpretation, nor am I resorting to a frivolous metaphor. The secret of plant subjectivity is that it makes sense of its own world, in its own manner, through its own channels of communication and ways of accessing, processing and acting upon visual, tactile and other types of stimuli [15]. Exactly how a human other receives and constructs her world is always something of an enigma, as twentieth-century phenomenology has evidenced, despite all its "analogical” trickery. More enigmatic yet is the subjective construction of the world by a plant, which we can barely glimpse through an approach I call phytophenomenology [16]. No phenomenological description of plant 
subjectivity can hope to exhaust the auto-production of vegetal meaning, or of meanings, much for the same reasons as the analogical appresentation of the human other cannot claim to have found direct access to her experience.

Dante poetically imagines the self-expression of plants in his Inferno, where the lot of certain human souls is to grow as trees in an enchanted forest. The narrator's act of violence, perpetrated against plants, liberates the secret meaning they harbor; after Dante detaches a twig, "from the broken shoot, came out at once / Both words and blood...” ([7], "Inferno,” Canto XIII, ll.43-44). "Both words and blood" betoken expression and life: the self-expression of life and plant life as a mode of expression. Virgil's warning that precedes this act seems particularly appropriate for all those who are about to face the secrets of plants: "If you break off / A little twig from one of these plants, / The thoughts you are thinking will be changed utterly” ([7], "Inferno,” Canto XIII, 1l.28-30). While they fall short of overt violence, contemporary studies in botany will violate the secret of vegetal life, if they reduce it to a mere object of knowledge, disrespecting its peculiar subjectivity. Outside hellish reality, where the plant speaks solely insofar as it is conceptually, economically, scientifically or physically violated-outside this all-too-prevalent reality, we must let it express itself in and as a secret. It is then that the "thoughts you are thinking will be changed utterly," to the point of bleeding into plant-thinking.

\section{References}

1. Tompkins, P.; Bird, C. The Secret Life of Plants: A Fascinating Account of the Physical, Emotional, and Spiritual Relations Between Plants and Man; Harper \& Row: New York, NY, USA, 1973.

2. Koechlin, F. Pflanzenpalaver: Belauschte Geheimnisse der botanischen Welt; Lenos Verlag: Basel, Switzerland, 2008.

3. Goodman, E. Plant Secrets; Charlesbridge Publishing: Watertown, DC, USA, 2009.

4. Suzuki, D. Smarty plants: Uncovering the secret world of plant behavior. Available online: http://www.cbc.ca/natureofthings/episode/smarty-plants-uncovering-the-secret-world-of-plantbehaviour.html (accessed on 24 December 2012).

5. Marder, M. The Life of Plants and the Limits of Empathy. Dialogue Can. Phil. Rev. 2013, 51, in press.

6. Aquinas. The Summa Theologica of Saint Thomas Aquinas; Encyclopedia Britannica: Chicago, IL, USA, 1952.

7. Dante. Divine Comedy. Sisson, C.H., Trans.; Oxford University Press: Oxford: UK, 1998.

8. Trewavas, A. Aspects of Plant Intelligence. Ann. Bot. 2003, 92, 1-20.

9. Jaillais, Y.; Chory, J. Unraveling the Paradoxes of Plant Hormone Signaling Integration. Nat. Struct. Mol. Biol. 2010, 17, 642-645.

10. Nietzsche, F. On the Genealogy of Morality; Clark, M., Swensen, A., Trans.; Hackett: Indianapolis, IN, USA, 1998.

11. Heidegger, M. What is Called Thinking? Gray, J.G., Trans.; Harper \& Row: New York, NY, USA, 1968. 
12. Heidegger, M. Letter on Humanism. In Basic Writings; Krell, D.F., Ed.; HarperCollins: San Francisco, CA, USA, 1977.

13. Gagliano, M.; Mancuso, S.; Robert, D. Towards Understanding Plant Bioacoustics. Tren. Pl. Sci. 2012, 17, 323-325.

14. Hegel, G.W.F. Aesthetics: Lectures on Fine Art; Knox, T., Trans.; Oxford University Press: Oxford, UK, 1998.

15. Chamowitz, D. What a Plant Knows: A Field Guide to the Senses of your Garden-and Beyond; Farrar, Straus \& Giroux: Oxford, UK, 2012.

16. Marder, M. Plant Intentionality and the Phenomenological Framework of Plant Intelligence. Plan. Sign. Beh. 2012, 7, 1365-1372.

(C) 2013 by the author; licensee MDPI, Basel, Switzerland. This article is an open access article distributed under the terms and conditions of the Creative Commons Attribution license (http://creativecommons.org/licenses/by/3.0/). 